\title{
Nabídka a organizace pohybových aktivit u dětí a dospělých se specifickými potřebami ve městě Jyväskylä, Finsko
}

\section{Offer and organization of physical activities for children and people with special needs in Jyväskylä, Finland}

\author{
Aleš Pátek
}

\section{Abstrakt:}

$V$ rámci čtyřměsiční zahranični stáže jsem měl možnost ziskávat zkušenosti na odboru sportu města Jyväskylä. Tento odbor, podobně jako $v$ městech České republiky, zajištuje sportovni aktivity obyvatel města a stará se o sportoviště ve městě Jyväskylä. Odbor má na starosti aplikované pohybové aktivity a zdravi prospěšné činnosti pro občany města bez rozdílu věku a fyzických schopností (dèti, senioři, osoby s postižením a lidé s chronickým onemocněním) a také pro osoby ohrožené sociálním vyloučením (nezaměstnaní, imigranti). Odbor zaměstnává 20 instruktorů, 30 peer instruktorů a 80 brigádníků, kteři organizují jednotlivé aktivity pro občany. Systém funguje už více jak třicet let a ve městě Jyväskylä patři v tomto ohledu ve Finsku k prikopnikům. Vnabídce aktivit se objevují nejen aktivity ve vodě, v tělocvičně, v posilovně a na hřišti, ale také v prírodě, na sněhu nebo na ledě. Pro nezaměstnané a osoby s postižením je většina aktivit zdarma a senioři a děti maji slevy.

\section{Abstract:}

During the four-months internship, I had the opportunity to gain experience in the sport department of Jyväskylä. This department like in the cities in Czech Republic provides sports activities for citizens and takes care of sport facilities in Jyväskylä. The department is responsi- 
ble for applied physical activities and health enhancing activities for citizens of all ages and physical capability (children, seniors, disabled people and people with chronical illnesses) and also for people at risk of social exclusion (the unemployed, immigrants). The department employs 20 instructors, 30 peer instructors and 80 part time instructors, who organize the activities for citizens. The system has been operating for more than thirty years and the city of Jyväskylä is a pioneer in this field in Finland. The range of activities includes not only activities in the water, gym and in the playground, but also outdoors, on the snow or on ice. For the unemployed and disabled people there is most of the activities for free and seniors and children have discounts.

Klíčová slova: Jyväskylä, APA, senioři, osoby s postižením, instruktoři.

Key words: Jyväskylä, APA, seniors, people with special needs, instructors.

\section{ÚVOD}

Město Jyväskylä se nachází ve střední části Finska v tzv. jezerní oblasti. Na konci roku 2012 mělo město 133482 obyvatel, z čehož 14 tisíc tvoří studenti. Ve městě najdeme téměř 360 sportovišt' a 200 sportovních klubů.

Odbor sportu města Jyväskylä ve Finsku má mimo jiné na starosti aplikované pohybové aktivity a zdraví prospěšné činnosti pro občany města bez rozdílu věku a fyzických schopností a také pro osoby ohrožené sociálním vyloučením. Za týden připraví téměř 400 lekcí různých sportovních aktivit, včetně APA (aplikovaných pohybových aktivit), sportovních kurzů a akcí.

\section{HLAVNÍ ČÁST}

\section{Popis odboru}

Cílem Odboru sportu je zajistit kvalitní podmínky budováním a udržováním sportovišt' pro podporu fyzické aktivity zdejších obyva- 
Offer and organization of physical activities for children and people with special needs in Jyväskylä, Finland Nabídka a organizace pohybových aktivit u dětí a dospělých se specifickými potřebami ve městě Jyväskylä, Finsko

tel. Odbor zaměstnává přibližně 140 lidí. Hlavní odpovědnost za plánování a realizaci patří dvěma městským odborům: již zmíněnému Odboru sportu a Odboru pro sociální a zdravotní služby. Společně plánují program aktivit pod vedením instruktorů pro skupiny osob tělesně a duševně postižených, seniorů, dětí a nezaměstnaných občanů, organizují přepravy těžce postižených osob do jednotlivých kurzů a spolupracují s dalšími subjekty (sportovní kluby, univerzita, domovy důchodců, domovy pro válečné veterány a domovy pro osoby se zdravotním postižením). Informují občany města o jimi připravovaných aktivitách prostřednictvím kalendáře, který je zveřejněn v místním tisku, časopisech, na www stránkách a v rádiích. Dále připravují 3-5 větších sportovních akcí konaných v průběhu roku. Pořádají školení pro sportovní instruktory formou vzdělávacích kurzů a vytvárí další APA projekty pro osoby se zdravotním postižením a pro seniory $\mathrm{v}$ regionu.

\title{
Instruktoři
}

Na Odboru sportu je zaměstnáno 20 specializovaných instruktorů, kteří pracují na plný úvazek. Jsou to většinou absolventi tělovýchovných programů univerzity nebo absolventi dvouletých kurzů pro sportovní instruktory. Další instruktoři jsou tzv. peer instruktoři, kterých je 30 a jsou vždy stejného věku jako samotní klienti. Skupina 80 brigádníků placených od hodiny je tvořena studenty tělesné výchovy nebo fyzioterapie. Další velká pomocná skupina jsou studenti tělesné výchovy nebo speciální pedagogiky, kteří $\mathrm{v}$ rámci praxe pomáhají na jednotlivých lekcích jako asistenti.

\begin{abstract}
Aktivity
Cvičení v tělocvičně jsou určeny pro děti, seniory, osoby s chronickým onemocněním, osoby s nadváhou a obezitou, nezaměstnané občany a osoby se zdravotním postižením. Mezi časté aktivity patří např́iklad: cvičení na židlích, cvičení na velkých míčích, gymnastika, míčové sporty, společenské, latinsko-americké a africké tance, strečink, posilování, zumba nebo pilates.
\end{abstract}


Cvičení v posilovně je určeno pro skupiny seniorů, osoby tělesně a duševně postižené, diabetiky, osoby s bolestmi zad a krční páteře a nezaměstnané občany. Hlavní náplní je posilování na strojích nebo cvičení s posilovacími pomůckami, strečink, úpolové sporty a kruhový trénink.

Cvičení ve vodě jsou vhodné pro děti, seniory, osoby s nadváhou a obezitou, nezaměstnané občany, osoby s problémy srdce a osoby se zdravotním postižením. Patří sem aqua-jogging, aqua-aerobic, terapeutické vodní aktivity, rekreační lekce plavání, plavání dětí z mateřských škol a dětí ze základní školy od 1. do 6. třídy.

Letní a zimní aktivity jsou většinou součástí jednorázových sportovních akcí nebo krátkodobých kurzů. Mezi letní aktivity patří: nordic walking, orientační běh, atletika, míčové hry, jízda na kole, plavání, turistika, kanoistika a mezi zimní aktivity patří: bruslení, sledge hokej, lyžování, snowboarding, sáňkování a chůze na sněžnicích.

\section{Nezaměstnaní občané}

V únoru 2013 bylo ve městě evidováno 9667 nezaměstnaných občanů a míra nezaměstnanosti tak tvořila 14,7 \%. Pouze občané, kteří aktivně hledají svoji novou práci, mají v rámci udržení své kondice $\mathrm{k}$ dispozici posilovnu, tělocvičnu a bazén. Dvakrát týdně si mohou využít posilovnu nebo si mohou zahrát míčové hry (florball a badminton) anebo mohou cvičit v tělocvičně pod vedením instruktora. Všechny tyto lekce jsou zdarma. Jednou za týden se mohou zúčastnit aqua-aerobiku, kde platí $2 €$ za vstup.

\section{Senioři}

Dle statistik z roku 2011 tvoří podíl obyvatel starších 65 let 14,9 \%, což je asi 19600 obyvatel. Pro tuto skupinu obyvatel Odbor sportu pořádá přibližně 180 lekcí za týden pod vedením instruktora. Mezi aktivity patř́ cvičení v tělocvičně, v posilovně, na bazéně, dále pak gymnastika, míčové hry, tance a cvičení na židlích. Cílovou skupinou jsou senioři se sníženou fyzickou kapacitou, s duševní poruchou, obezitou nebo nadváhou, s problémy zad a inaktivní senioři. 
Offer and organization of physical activities for children and people with special needs in Jyväskylä, Finland Nabídka a organizace pohybových aktivit u dětí a dospělých se specifickými potřebami ve městě Jyväskylä, Finsko

\section{Osoby se specifickými potřebami}

Odbor sportu připraví přibližně 200 lekcí pod vedením instruktorů za týden. Lekce jsou určeny pro osoby tělesně postižené (dětská mozková obrna, rozštěpy páteře, ochrnutí po poranění míchy), dále pro osoby mentálně postižené, osoby s poruchou autistického spektra a osoby se zrakovým a sluchovým postižením. Mezi nejpopulárnější činnosti patří cvičení v tělocvičně, posilovně, na bazéně a míčových her. Na těchto lekcích působí studenti tělesné výchovy, fyzioterapie nebo speciální pedagogiky jako osobní asistenti pro ty, kteří potřebují pomoc. Hlavním cílem těchto lekcí je naučit klienty novým motorickým schopnostem a nabídnout jim nové zážitky.

\section{Transport}

Odbor sportu má na starosti také přepravu osob na bazén a do posilovny. Cílem přepravy je umožnit všem osobám, které mají potíže se samostatně dopravit na bazén, účastnit se cvičení po celý rok. Tato služba je k dispozici v zimních měsících, kvůli sněhu, náledí na chodnících a tmě. Přeprava seniorů je organizovaná dle přesně stanoveného harmonogramu (v konkrétní den v týdnu se sváží osoby z konkrétního předměstí). Náklady na přepravu hradí Odbor sportu, senioři si platí pouze poplatek za bazén. Za tento poplatek si mohou vybrat vodní aerobik s instruktorem, plavání, posilování v moderně vybavené posilovně, která je ve stejné budově anebo mohou využít perličkové koupele, vodní masáže a saunu. Přeprava pro těžce postižené osoby a děti se specifickými potřebami je organizovaná jedenkrát za týden.

\section{Ceny}

Občané města Jyväskylä starší 70 let mají nárok na získání karty pro seniory. Karta stojí $70 €$ a je platná po dobu jednoho roku od data zakoupení. Karta může být použita ve všední dny, maximálně jedenkrát denně, na plavání nebo posilovnu na pěti různých místech města. Držitel karty se nemůže účastnit lekcí pod vedením instruktora. Lekce s instruktorem 
stojí 6-9 $€$ pro dospělé osoby. Senioři a osoby se zdravotním postižením platí 4,50-6,50 €. Konečná cena záleží na středisku, kde lekce probíhají. Permanentka na 15 vstupů pro dospělé stojí $63 €$, senioři a osoby se zdravotním postižením platí $49 €$. Na podzim a na jaře je vždy organizováno 15 lekcí s instruktorem.

\section{Sportovní zařízení}

V Jyväskyle se provozuje více než 70 různých typů sportů a nachází se zde téměř 360 sportovních zařízení, několik běžeckých tratí kolem jezer a v zimě asi $500 \mathrm{~km}$ upravovaných běžkařských tratí. Provoz sportovních zařízení a úpravu těchto tratí stojí Odbor zhruba 15 milionů $€$ za rok. Mezi nejoblíbenější halové sporty patří různé druhy míčových her, posilování, tanec a plavání. $Z$ tohoto důvodu město disponuje několika krytými bazény, halami s lední plochou, tělocvičnami, posilovnami a dalšími zařízeními.

Velmi oblíbeným sportem pro dospělé je běh, kterému se ve Finsku věnuje asi 1,8 milionu lidí. Podobné je to v zimě, kdy se téměř 1,5 milionu Finů věnuje běžeckému lyžování. V Jyväskylä regionu je k dispozici patnáct běžkařských středisek a více než 50 kilometrů je osvětlených. Tratě pro běžecké lyžování a stezky pro jogging jsou zdarma k použití po celý rok. Téměř každé školní hřiště je v zimě přetvořeno na ledovou plochu, která je využívána jak pro vyučování tělesné výchovy, tak pro širokou veřejnost. Na všech zamrzlých jezerech jsou upravovány dráhy pro bruslení a tratě pro běžecké lyžování. V létě jsou volně $\mathrm{k}$ dispozici hřiště pro míčové hry, dětská hřiště, parky a pláže u jezer s toaletou, šatnou a sprchou.

\section{Doplňkové služby}

V závislosti na požadavcích klienta je k dispozici fyzioterapeut, který může pomoci v mnoha směrech. Analyzuje pohybový program klienta, poskytuje pomoc při nemoci či zranění, vypracovává individuální cvičební plán nebo zařazuje klienta do pro něj ideální cvičební skupiny. Odbor dále pořádá školení pro sportovní instruktory formou vzdělávacích 
Offer and organization of physical activities for children and people with special needs in Jyväskylä, Finland

Nabídka a organizace pohybových aktivit u dětí a dospělých se specifickými potřebami ve městě Jyväskylä, Finsko

kurzů. Shromažd'ují literaturu, videa, multimediální programy a další materiál ohledně osob se specifickými potřebami pro další potřeby vzdělávání široké veřejnosti. Odbor nabízí konzultace, výuku a výcvik osob se specifickými potřebami pro fyzioterapeuty, učitele, instruktory, organizace a osobní asistenty. Poskytuje služby asistenta pro osoby se specifickými potřebami v průběhu cvičení. A v neposlední řadě půjčuje sportovně-kompenzační pomůcky pro občany města.

\section{ZÁVĚR}

Odbor sportu ve městě Jyväskylä, který zajišt'uje sportovní aktivity obyvatel města a stará se o většinu sportovišt', byl použit jako model pro ostatní města ve Finsku. Př́iprava a organizace aplikovaných pohybových aktivit pro občany města je zde na vysoké úrovni. Tyto služby jsou hojně využívány a občané jsou tak velmi pohybově aktivní. Pro lepší představu fungování tohoto systému je k dispozici několik fotografií a videa.

\section{LITERATURA}

Ješina, O., Kudláček, M., et al. (2012). Aplikovaná tělesná výchova. Olomouc: Univerzita Palackého v Olomouci.

\section{INTERNETOVÉ ZDROJE:}

http://jkl.fi/liikunta/ohjattu_liikunta/kuntoneuvola http://www.jkl.fi/liikunta/erlikalenteri/aikuiset/Ohjattujen\%20liikuntaryhmien $\% 20$ hinnasto

http://www.jkl.fi/liikunta/erlikalenteri/aikuiset/tyoikaisten_kunto_ja_ terveysliikunta/tyottomien_wire_liikunta http://www.jkl.fi/liikunta/erlikalenteri/iakkaat/seniorikortti70 http://www.jkl.fi/liikunta/hallinto http://www.jkl.fi/liikunta/ohjattu_liikunta/uimahallikuljetukset http://www.jkl.fi/liikunta/sisaliikuntapaikat http://www.jkl.fi/liikunta/ulkoliikuntapaikat 
http://www.jyvaskyla.fi/info/pahkinankuoressa

http://www.jyvaskyla.fi/info/tietoja_jyvaskylasta/kymmenen_suurinta vertailu

http://www.jyvaskyla.fi/liikunta/seurat

\section{KONTAKT:}

Mgr. Aleš Pátek, alespatek@post.cz

\section{PŘÍLOHA}

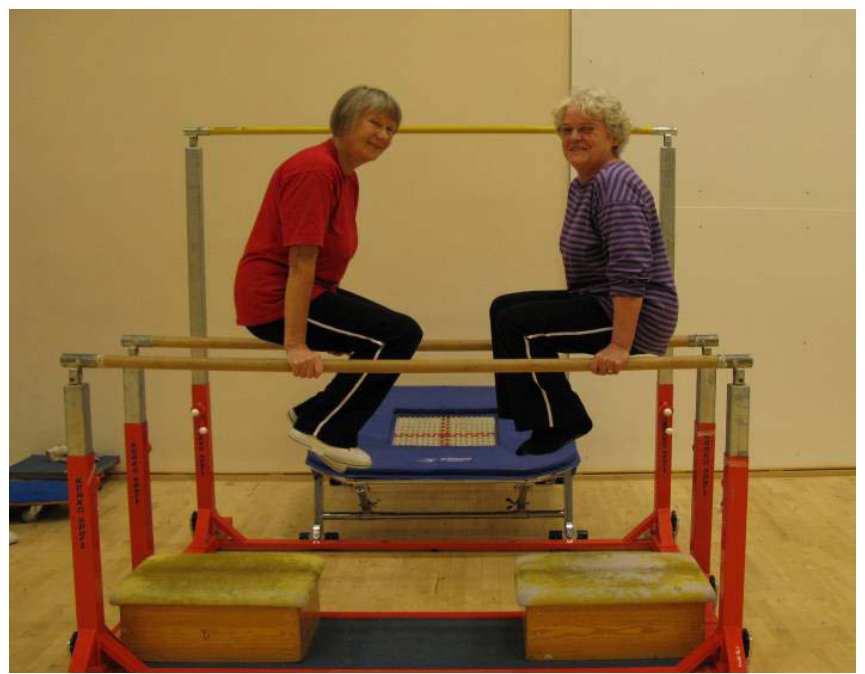

Obr. 1: Gymnastika pro seniory 
Offer and organization of physical activities for children and people with special needs in Jyväskylä, Finland

Nabídka a organizace pohybových aktivit u dětí a dospělých se specifickými potřebami ve městě Jyväskylä, Finsko

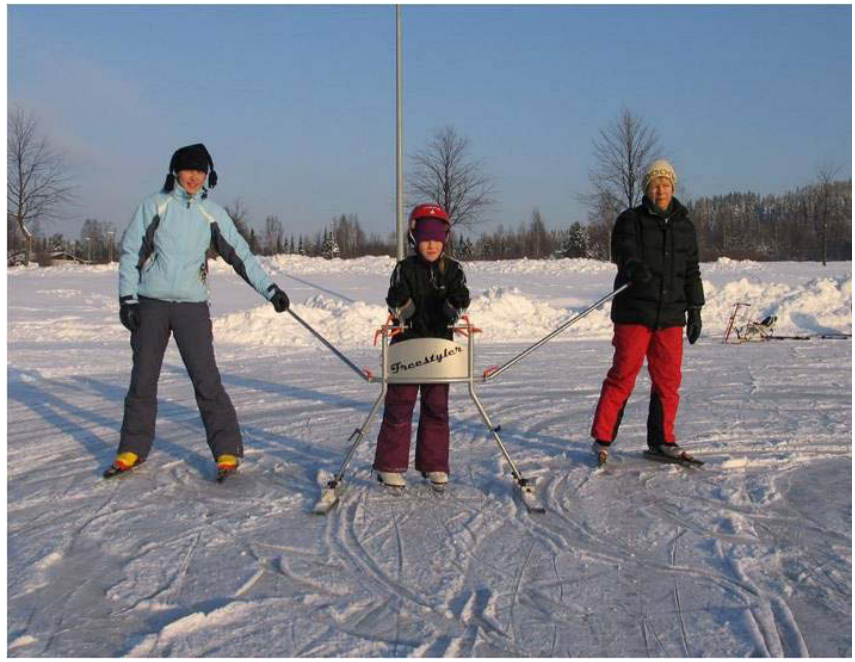

Obr. 2: Bruslení s choditkem

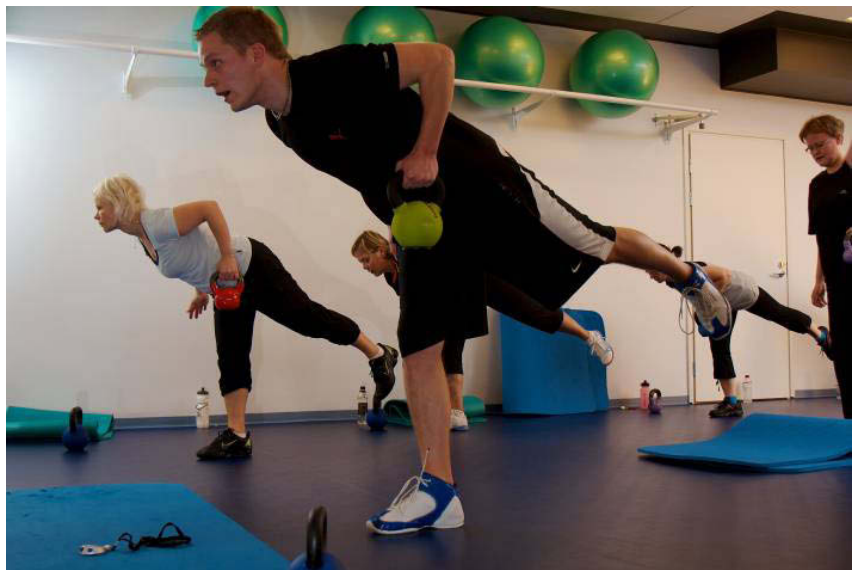

Obr. 3: Cvičení pro nezaměstnané občany 


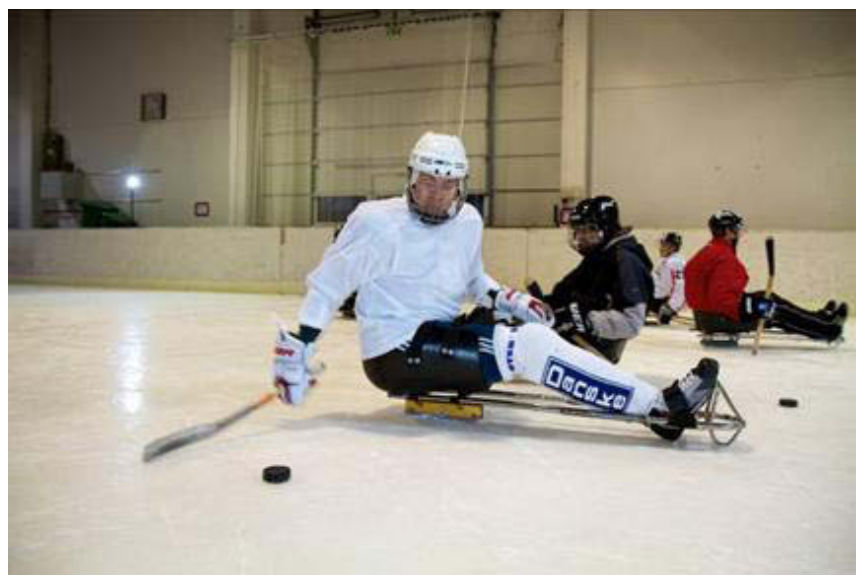

Obr. 4: Sledge hokej

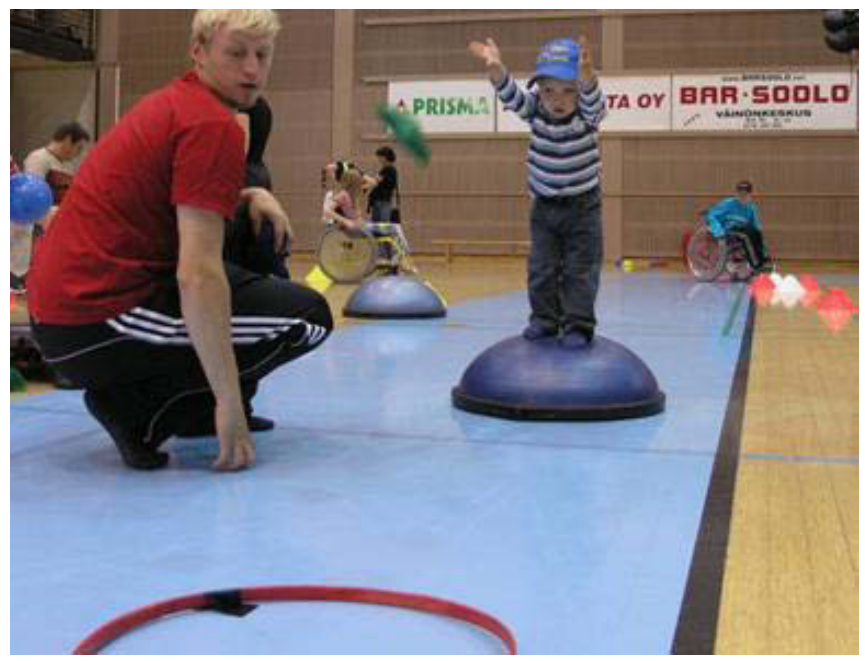

Obr. 5: APA pro zdravotně postižené děti 
Offer and organization of physical activities for children and people with special needs in Jyväskylä, Finland

Nabídka a organizace pohybových aktivit u dětí a dospělých se specifickými potřebami ve městě Jyväskylä, Finsko

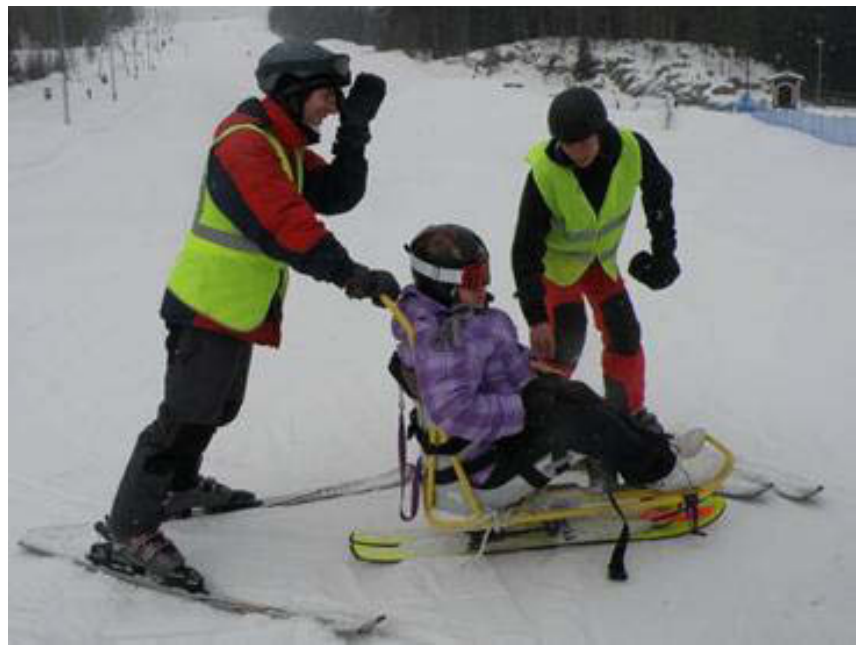

Obr. 6: Lyžování na biski

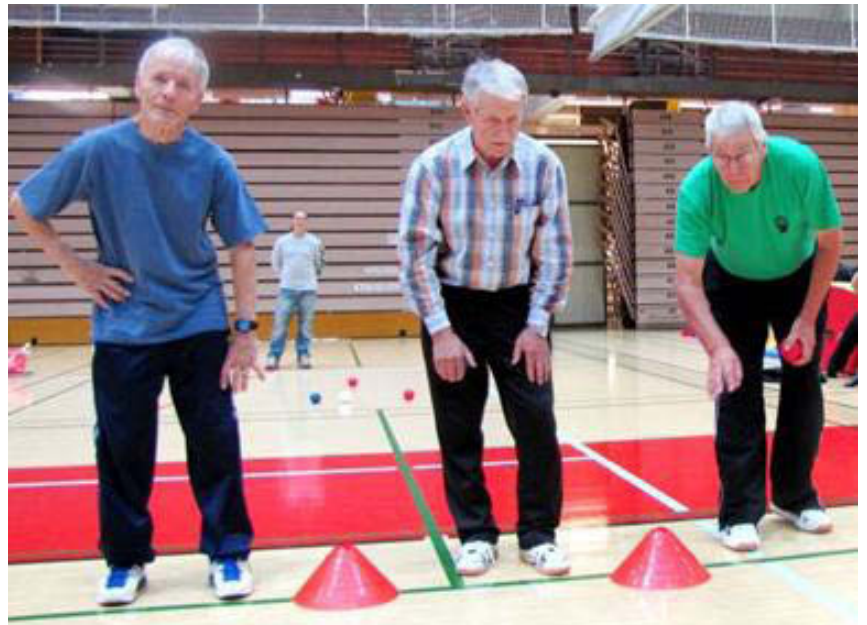

Obr. 7: Hra Boccia pro seniory 


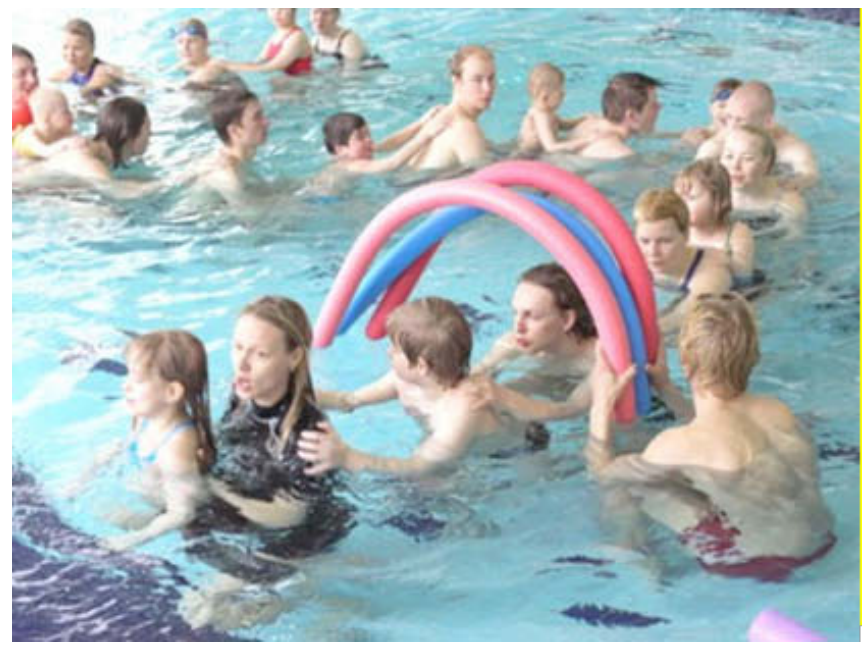

Obr. 8: Plavání pro zdravotně postižené děti

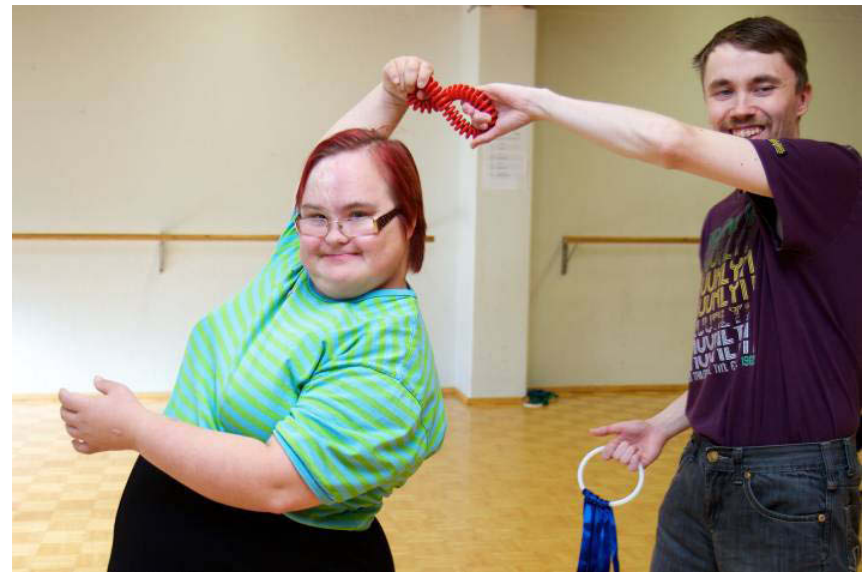

Obr. 9: Tanec pro zdravotně postižené 
Offer and organization of physical activities for children and people with special needs in Jyväskylä, Finland

Nabídka a organizace pohybových aktivit u dětí a dospělých se specifickými potřebami ve městě Jyväskylä, Finsko

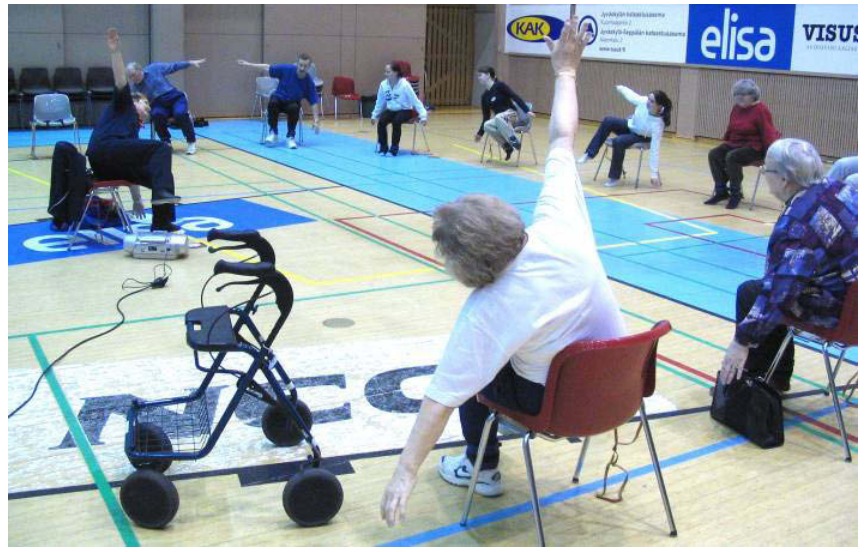

Obr. 10: Cvičení na židlích pro seniory

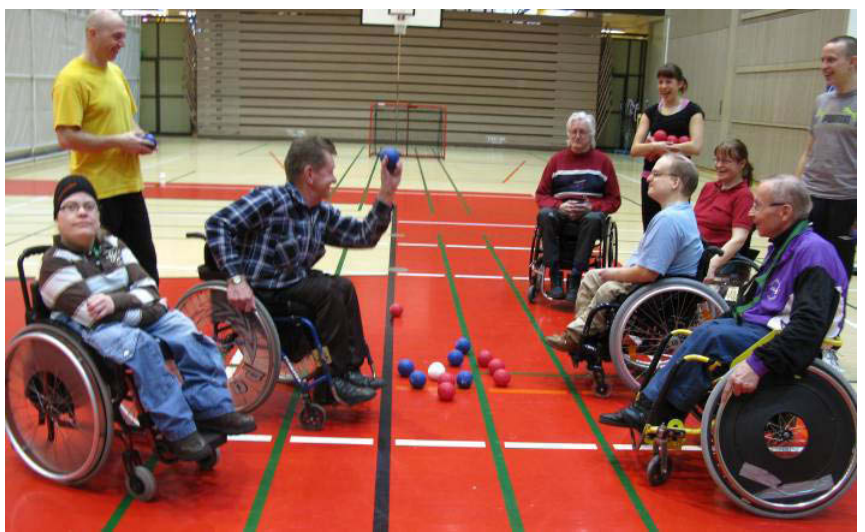

Obr. 11: APA pro vozíčáre 


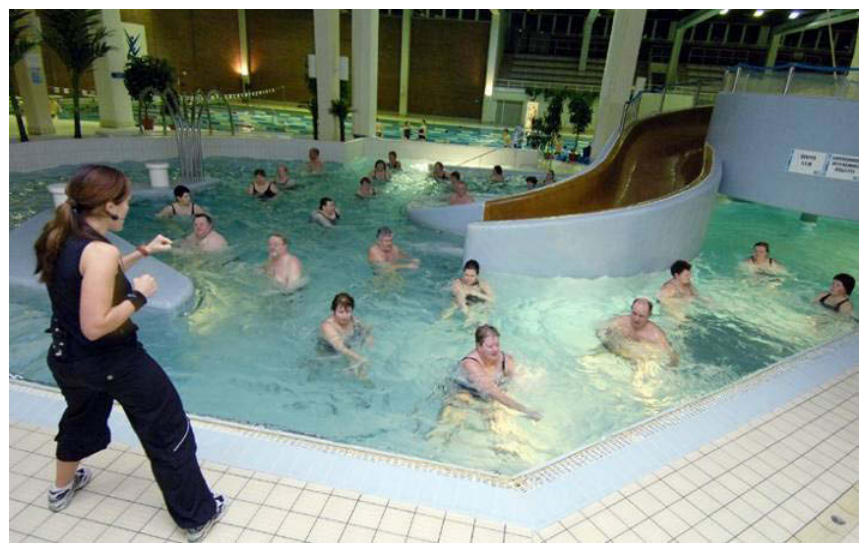

Obr. 12: Aqua-aerobik pro seniory 